\section{'M 17' Gummy Stem Blight Resistant Pickling Cucumber Inbred}

\author{
Todd C. Wehner ${ }^{1}$ and Paul C. St. Amand ${ }^{2}$ \\ Department of Horticultural Science, Box 7609, North Carolina State \\ University, Raleigh, NC 27695-7609

\section{Richard L. Lower ${ }^{3}$ \\ Department of Horticulture, University of Wisconsin, Madison, WI 53706}

Additional index words. Cucumis sativus, vegetable breeding, cultivar, variety, germplasm, disease resistance, Didymella bryoniae

'M 17' is a monoecious, pickling cucumber (Cucumis sativus L.) inbred with moderate resistance to gummy stem blight [Didymella bryoniae (Auersw.) Rehm] under North Carolina field conditions. In our research, 'M 17' was the most resistant cucumber having American pickling-type fruit (St. Amand and Wehner, 1995; Wehner and St. Amand, 1993). Its resistance was not as high as the slicing cucumbers 'Slice' or 'Homegreen \#2', but was similar to that of 'Poinsett 76'.

\section{Origin}

'M 17' originated from the cross of the southern U.S.-adapted, disease-resistant, high fruit quality, monoecious inbred 'Chipper', with the northern U.S.-adapted, disease-resistant, high fruit quality, monoecious inbred 'Wisconsin SMR 18' (Fig. 1). Segregating generations were tested, selected, and selfpollinated to develop an elite inbred. Lines were inbred to the $\mathrm{F}_{5}$ generation in the greenhouse and field, testing for yield, earliness, fruit quality, and disease resistance in general. Following that, all available $\mathrm{F}_{5}$ lines were cycled through five generations of selection for gummy stem blight resistance in the greenhouse, followed by self-pollination to develop the inbred $95 \mathrm{GH} 430 \mathrm{~S}_{10}$, which was designated 'M 17'.

\section{Description}

Vines. 'M 17' has medium-large vines, similar to those of 'Sumter', but smaller than

Received for publication 18 Jan. 1996. Accepted for publication 20 July 1996. The use of trade names in this publication does not imply endorsement by the NCARS of the products named, nor criticism of similar ones not mentioned. We gratefully acknowledge the technical assistance of Rufus R. Horton, Jr. The cost of publishing this paper was defrayed in part by the payment of page charges. Under postal regulations, this paper therefore must be hereby marked advertisement solely to indicate this fact. ${ }^{1}$ Professor.

${ }^{2}$ Former Graduate Research Assistant; currently, U.S. Dept. of Agriculture/Agricultural Research Service Postdoctoral Research Associate, Agronomy Dept., Kansas State Univ., 2004 Throckmorton Hall, Manhattan, KS 66506-5501.

${ }^{3}$ Professor. those of 'Wisconsin SMR 18'. It has an indeterminate plant habit, with medium-sized leaves. Vine growth is vigorous under the hot, humid conditions common to the spring and summer production seasons of the midwestern and southeastern United States. and 3 years of performance trials at Clinton, N.C. ${ }^{z}$ N.C. 5 to 6 moderate, 7 to $8=$ advanced, $9=$ plant dead).
Flowering habit. The plants are monoecious, nonparthenocarpic, and reach 50\% flowering when plants are $\approx 30$ days old, similar to 'Sumter' and 'Wisconsin SMR 18'. Flowering is sequential and usually begins at the first true-leaf node. Yield is similar to that of other elite, monoecious inbred pickling cucumbers, like 'Sumter' and 'Wisconsin SMR 18', as is the percentage of staminate nodes among the first five nodes at full flowering (Table 1).

Fruit. 'M 17' has medium-long fruit, and white spines. Vine and fruit color are often similar in cucumbers and are both light green in 'M 17' (Table 1, Fig. 2). Fruit color is very light green with almost-white areas, being much lighter than 'Sumter' and 'Calypso', and lighter even than 'Wisconsin SMR 18' (Table $1)$. The fruit are coarse-spined, moderately warted, and have a slight speckling and striping (not uniform green). 'M 17' produces fruit that are cylindrical with rounded ends, with a shape rating of 6 (on a 1 to 9 scale), a seedcell size rating of 6 , and a length : diameter (L : D) ratio of 3.1:1 for 35-mm-diameter fruit, simi-

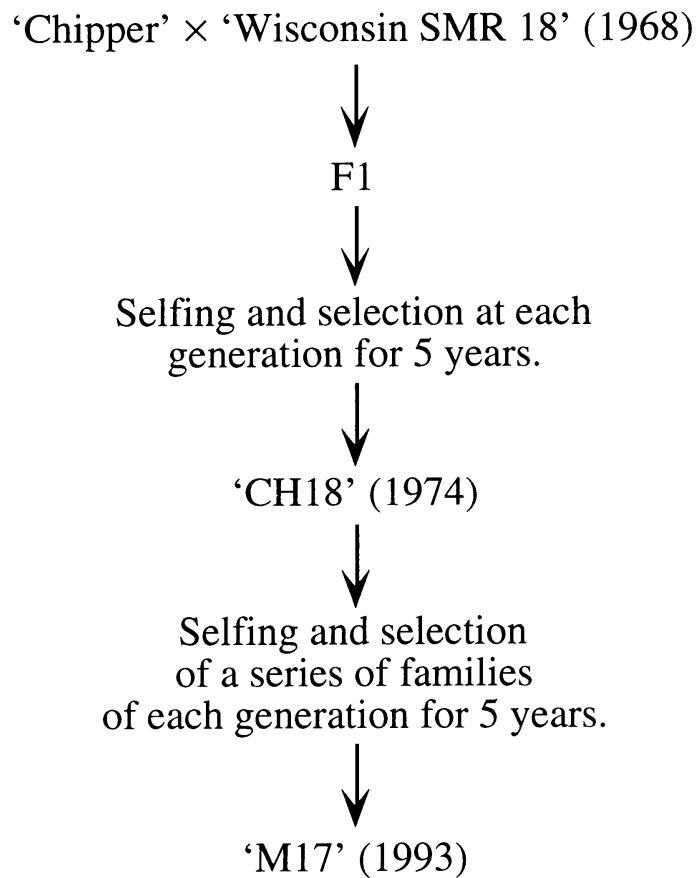

Fig. 1. Pedigree of NCSU 'M 17' as a selection from a family (CH18) in the NCSU germplasm collection.

Table 1. Horticultural performance of 'M 17' and five standard pickling cucumber cultivars in two seasons

\begin{tabular}{|c|c|c|c|c|c|c|c|c|c|}
\hline Cultigen & 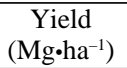 & $\begin{array}{c}\text { Staminate } \\
\text { nodes }(\%)^{\mathrm{y}}\end{array}$ & $\begin{array}{l}\text { Vine } \\
\text { color }^{\mathrm{x}}\end{array}$ & $\begin{array}{l}\text { Fruit } \\
\text { color }^{x}\end{array}$ & $\begin{array}{c}\text { Fruit } \\
\text { shape }^{w}\end{array}$ & $\begin{array}{l}\text { Seed- } \\
\text { cell }^{v}\end{array}$ & $\begin{array}{l}\mathrm{L}: \mathrm{D} \\
\text { ratio }\end{array}$ & $\begin{array}{c}\text { Firmness } \\
(\mathrm{N})\end{array}$ & $\begin{array}{l}\text { GSB } \\
\text { res. }^{\text {u }}\end{array}$ \\
\hline$\overline{\mathrm{M} 17}$ & 14.6 & 46 & 5 & 3 & 6 & 6 & 3.1 & 85 & 2 \\
\hline Calypso & 25.2 & 20 & 6 & 6 & 6 & 6 & 3.1 & 71 & 3 \\
\hline Johnston & 25.8 & 14 & 7 & 7 & 6 & 6 & 3.3 & 71 & 3 \\
\hline Raleigh & 23.6 & 10 & 6 & 7 & 6 & 6 & 3.2 & 67 & 4 \\
\hline Sumter & 17.2 & 51 & 7 & 5 & 6 & 8 & 3.1 & 76 & 3 \\
\hline Wis. SMR 18 & 16.1 & 47 & 5 & 4 & 5 & 4 & 3.0 & 76 & 5 \\
\hline $\operatorname{LSD}_{(0.05)}$ & 3.6 & 12 & 1 & 1 & 1 & 1 & 0.1 & 4 & 1 \\
\hline
\end{tabular}

${ }^{2}$ Data are means of three years, two seasons, three replications, and six harvests of field trials near Clinton,

yPercentage of staminate nodes of the first five nodes on five plants per plot.

${ }^{\mathrm{x}}$ Color rated 1 to 9 ( 1 to $3=$ light green, 4 to $6=$ medium green, 7 to $9=$ dark green $)$.

"whape rated 1 to 9 ( 1 to $3=$ poor, 4 to $6=$ intermediate, 7 to $9=$ excellent).

vSeedcell rated 1 to 9 ( 1 to $3=$ large, 4 to $6=$ intermediate, 7 to $9=$ small).

"Gummy stem blight rated for foliar lesions on a 0 to 9 scale $(0=$ no symptoms, 1 to $2=$ trace, 3 to $4=$ slight, 


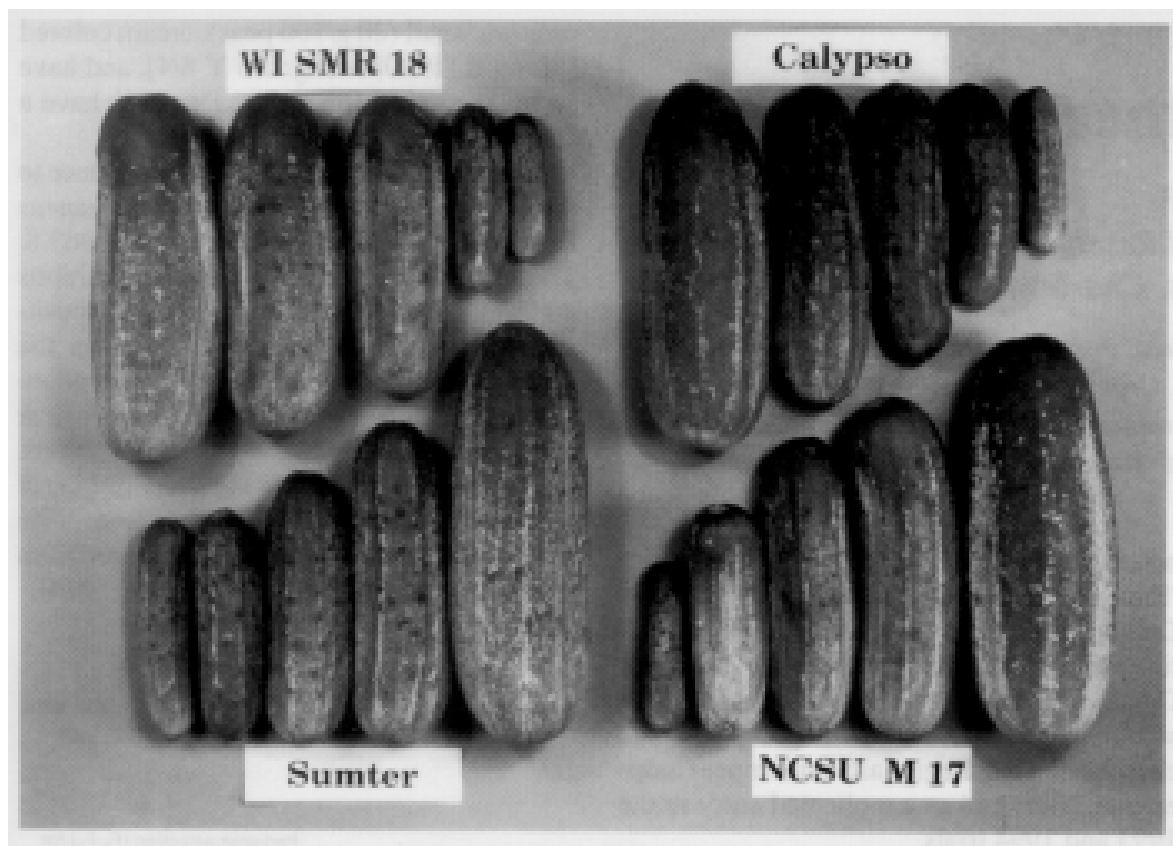

Fig. 2. Fruit of 'M 17' compared to standard pickling cucumbers 'Sumter', 'Wisconsin SMR 18', and 'Calypso'.

Table 2. Gummy stem blight ratings of 'M 17' and other cultigens used for pickling and slicing cucumber production in southern U.S. areas where the disease is a problem.

\begin{tabular}{lccc}
\hline \hline & & Field trials & \\
\cline { 2 - 4 } Cultigen & Inoculated $^{\mathrm{y}}$ & Noninoculated $^{\mathrm{x}}$ & Greenhouse $^{\mathrm{w}}$ \\
\hline Slice & 2.9 & --- & 1.5 \\
Homegreen \#2 & 3.0 & --- & 1.7 \\
M 17 & 3.2 & 1.7 & 2.0 \\
Poinsett 76 & 4.2 & 2.7 & 1.8 \\
Chipper & 4.4 & --- & --- \\
PI 200818 & 4.2 & --- & 4.3 \\
Sumter & 4.9 & 2.7 & --- \\
Calypso & 5.3 & 2.3 & --- \\
Wis. SMR 18 & 5.7 & 4.7 & 6.9 \\
LSD $_{(0.05)}$ & 0.6 & 1.0 & 0.7
\end{tabular}

${ }^{2}$ Rated for foliar lesions on a 0 to 9 scale $(0=$ no symptoms, 1 to $2=$ trace, 3 to $4=$ slight, 5 to 6 moderate, 7 to $8=$ advanced, 9 = plant dead). "---" = not tested.

yata are means over 4 years $(1981,1982,1983,1986)$ and three replications for plants inoculated with 12 isolates of Didymella bryoniae.

${ }^{x}$ Data are means over 2 years $(1991,1992)$, two seasons (spring, summer), and three replications for plants not inoculated with Didymella bryoniae.

"Data are means over two tests and six replications for plants inoculated with Didymella bryoniae in the greenhouse in 1992. lar to 'Calypso' (Table 1). Fruit keeping ability and balloon bloater resistance are similar to 'Sumter' and 'Calypso' (data not shown). Fruit firmness, measured with a McCormick punch tester (McCormickFruit Tech, Yakima, Wash.) with an 8-mm-diameter tip, was higher than for any other cultivars tested in our trials (Table 1).

Resistance. 'M 17' has moderate resistance to gummy stem blight in greenhouse and North Carolina field tests (Tables 1 and 2). Neither parent of 'M 17' has much resistance to gummy stem blight, so resistance in ' $\mathrm{M} 17$ ' may be due to a combination of several minor genes for resistance from each parent or to a unique combination between its nuclear and extranuclear genes. In studies of inheritance of resistance, there was evidence of a maternal effect in the progeny of crosses involving ' $M$ 17' (St. Amand, 1993).

As a routine part of the development of inbred lines in the breeding program, ' $\mathrm{M} 17$ ' was selected for moderate to high field resistance to the following six diseases common to the United States (data not shown): cucumber mosaic virus, downy mildew [Pseudoperonospora cubensis (Berk. \& M. A. Curtis) Rostovzev], powdery mildew [Spaerothecafuliginea (Schlechtend.:Fr.) Pollacci], anthracnose [Colletotricum orbiculare (Berk. \& Mont.) Arx], angular leaf spot [Pseudomonas syringae van Hall pv. lachrymans (Smith and Bryan) Young et al.], and belly rot (Rhizoctonia solani Kühn).

\section{Availability}

Small amounts of breeder's seed may be obtained by writing to T.C.W.

\section{Literature Cited}

St. Amand, P.C. 1993. Gummy stem blight in cucumber: testing methods, pathogenicity of isolates, and inheritance of resistance. PhD Diss., North Carolina State Univ., Raleigh.

St. Amand, P.C. and T.C. Wehner. 1995. Greenhouse, detached-leaf, and field testing methods to determine cucumber resistance to gummy stem blight. J. Amer. Soc. Hort. Sci. 120:673680.

Wehner, T.C. and P.C. St. Amand. 1993. Field tests for cucumber resistance to gummy stem blight in North Carolina. HortScience 28:327-329. 